\title{
Effects of rocky shore coseismic uplift and the 2010 Chilean mega-earthquake on intertidal biomarker species
}

\author{
Juan Carlos Castilla ${ }^{1, *}$, Patricio H. Manríquez ${ }^{2,3}$, Andrés Camaño ${ }^{4}$ \\ ${ }^{1}$ Departamento de Ecología y Centro FONDAP de Ecología y Biodiversidad, Facultad de Ciencias Biológicas, \\ Pontificia Universidad Católica de Chile, Casilla 114-D, Santiago, Chile \\ ${ }^{2}$ Instituto de Biología Marina 'Dr. Jürgen Winter' and ${ }^{3}$ Laboratorio Costero de Recursos Acuáticos de Calfuco, \\ Facultad de Ciencias, Universidad Austral de Chile, Casilla 567, Valdivia, Chile \\ ${ }^{4}$ Arauco, Avenida El Golf 150, Casilla 880, Santiago, Chile
}

\begin{abstract}
The devastating earthquake (moment magnitude: $8.8 \mathrm{MW}$ ) that struck Chile on 27 February 2010 and the following tsunami waves produced widespread damage, coastal coseismic uplifts, and large-scale mortality of rocky intertidal and shallow subtidal organisms. The effects were particularly remarkable around the Gulf of Arauco, Santa María Island and the Bay of Concepción ( 36 to $38^{\circ} \mathrm{S}$ ). Measurements of rocky intertidal and shallow subtidal belt-forming (biomarker) species conducted a few weeks after the earthquake indicated coastal uplifts ranging from $\sim 0.2$ to $3.1 \mathrm{~m}$, which are similar to uplifts estimated by FitzRoy (1839; Voyages of the Adventure and Beagle, Vol. II) and Darwin (1839; Voyages of the Adventure and Beagle, Vol. III) after the 1835 Chilean earthquake. In major uplifted sites, there was massive mortality of the main intertidal and shallow subtidal beltforming species, such as lithothamnioid melobesioid coralline algae, brown kelps and mussels, and dramatic changes in the marine rocky intertidal ecosystem. We suggest that in the southeastern Pacific, drastic and rapid coastal deformations seriously impinge on rocky shore populations, communities and ecosystems and may have significance for management and conservation practices, as for example in connection with alterations of parental stocks and recruitment rates.
\end{abstract}

KEY WORDS: Drastic events · Coastal deformation · Intertidal biomarkers · Massive mortality Resale or republication not permitted without written consent of the publisher

\section{INTRODUCTION}

In the southeastern Pacific, the Nazca tectonic plate is being subducted beneath the South American plate and mega-earthquakes occur every 10 yr (Madariaga et al. 2010). Chile is one of the regions in the world where large earthquakes ( $\geq 7 \mathrm{MW}$ ) and rapid coastal uplift/subsidence are frequent (Lomnitz 1970, Comte et al. 1986, Ruegg et al. 2009). On 27 February 2010 at 03:34 h, local time, an 8.8 MW mega-earthquake, the fifth largest instrumentally recorded, occurred off the south-central coast between Concepción and Constitución $\left(\sim 35\right.$ to $\left.38^{\circ} \mathrm{S}\right)$. The epicenter was located $\sim 110$ to $120 \mathrm{~km}$ northeast of Concepción $\left(36^{\circ} 49^{\prime} \mathrm{S}, 73^{\circ} 03^{\prime} \mathrm{W}\right)$ at a depth of $6.2 \mathrm{~km}$, and the rupture zone was $\sim 500$ to $600 \mathrm{~km}$ long (Farías et al. 2010, Madariaga et al. 2010). The characteristics of this earthquake were similar in many respects to those of a Chilean earthquake in 1835 that was reported by FitzRoy (1839) and Darwin $(1839,1846)$. There were preliminary verbal reports of coastal uplifts along the rupture zone at mainland sites as well as on Santa María Island $\left(37^{\circ} 02^{\prime} \mathrm{S}, 73^{\circ} 31^{\prime} \mathrm{W}\right)$ in the Gulf of Arauco (Fig. 1). In addition, the earthquake generated tsunami waves up to $10 \mathrm{~m}$ causing enormous destruction and devastation in coastal villages (Marín et al. 2010).

Santa María Island $\left(35 \mathrm{~km}^{2}\right.$ ) sits $75 \mathrm{~km}$ landward from the southern end of the Concepción oceanic seis- 


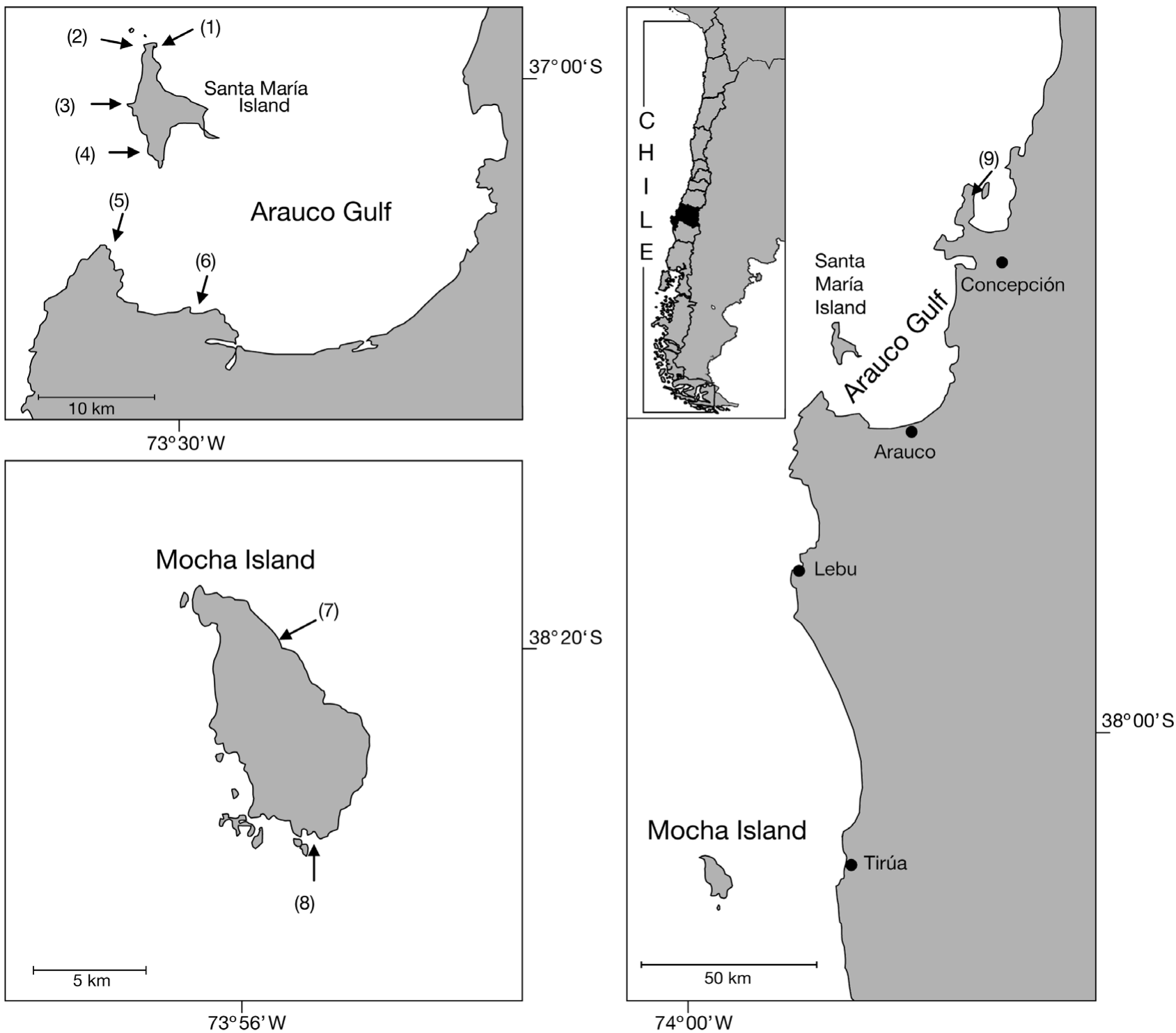

Fig. 1. Location of visited earthquake sites during 2010 (Garmin eTrex GPS). Santa María Island (18 to 21 March and 13 to 14

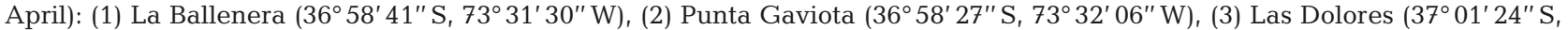

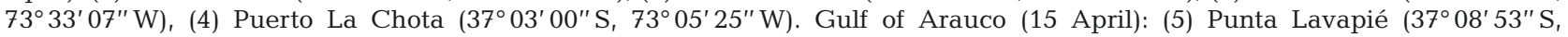

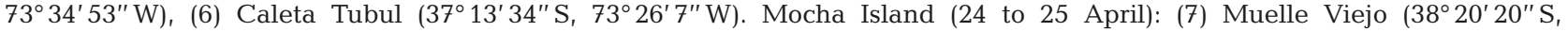

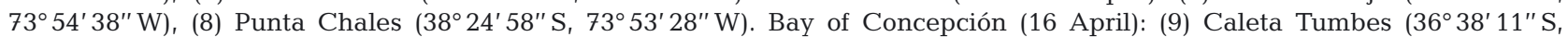
$\left.73^{\circ} 05^{\prime} 31^{\prime \prime} \mathrm{W}\right)$

mic trench and is $\sim 12 \mathrm{~km}$ above where the Nazca tectonic plate is being subducted beneath the South American plate. In fact, the island is the result of earthquake uplifts and deformations that have occurred since the late Pleistocene (Melnick et al. 2006). Major coseismic uplifts on Santa María Island and adjacent mainland sites have previously been reported, although not quantified (e.g. uplifts caused by an earthquake in 1751 ( 8.5 MW; Lomnitz 1970, Comte et al. 1986). Santa María Island was also in the rupture zone of the $8.2 \mathrm{MW}$ mega-earthquake (Melnick et al.
2006) that occurred on 20 March 1835. HMS 'Beagle' visited the region in March, and FitzRoy and Darwin made observations based on the visible evidence of dead shellfish, water marks, surroundings and the verbal testimony of inhabitants. Darwin (1846) summarized FitzRoy's uplift reports: $2.4 \mathrm{~m}$ for the southern end, $2.7 \mathrm{~m}$ for the central part and $3 \mathrm{~m}$ for the northern end of the island. On the mainland, at Tubul (Fig. 1), there was an uplift of $1.8 \mathrm{~m}$. Uplifts of $2.4 \mathrm{~m}$ for the Quiriquina Island $\left(36^{\circ} 37^{\prime} \mathrm{S}, 73^{\circ} 03^{\prime} \mathrm{W}\right)$ and 1.5 to $2.4 \mathrm{~m}$ for Talcahuano harbor $\left(36^{\circ} 43^{\prime} \mathrm{S}, 73^{\circ} 07^{\prime} \mathrm{W}\right)$ were also 
reported. Darwin (1839, p. 414) vividly described the effects of the earthquake on rocky shores:

I do not wish to exclude the small starts which accompany earthquakes, as on the coast of Chile; and by such movement beds of shell might easily be uplifted, even in position exposed to heavy surf, without undergoing any attrition: for instance, in 1835, a rocky flat off the island of Santa Maria was at one blow up-heaved above highwater marks, and was left covered with gaping and putrefying mussel-shells, still attached to the bed on which they had lived.

The $\sim 2 \mathrm{~m}$ coseismic uplift contour derived from these data has been interpreted as being parallel to the northeast-striking reverse fault system (Melnick et al. 2006). The rocky shore-level changes reported by FitzRoy (1839) and Darwin (1839, 1846) were determined using mostly the emerged upper limit of the dead belt of Mytilus as a pre-earthquake biomarker of the lower limit of the intertidal zone.

\section{MATERIALS AND METHODS}

Field visits. In order to evaluate biotic impacts and coseismic uplifts on rocky shore intertidal belts and communities following the mega-earthquake in February 2010, we visited 9 sites. These sites imclude most of those reported by FitzRoy (1839) and Darwin (1839, 1846), and full details are given in Fig. 1.

Biomarkers. Belts of intertidal sessile invertebrates and upper subtidal algae have been used as conservative biomarkers to evaluate the coseismic shore uplifts associated with earthquakes (National Academy of Sciences 1972, Bodin \& Klinger 1986, Castilla 1988, Castilla \& Oliva 1990, Carver et al. 1994, Ortlieb et al. 1996, Awata et al. 2008, Farías et al. 2010). As a first direct approach for measuring coseismic uplift, we used the vertical elevation of the white fringe zone formed by dead coralline lithothamnioid melobesioid algae (Synarthrophyton spp, Lithophyllum spp; I. Meneses pers. comm.) and of the dead holdfasts of the bull-kelp Durvillaea antarctica and the kelp Macrocystis pyrifera. The coralline algae lose pigment and appear white (bleached) after being exposed to solar radiation and elevated temperatures (Ortlieb et al. 1996, Ramírez-Herrera \& Zamorano 2002, Farías et al. 2010). In Chile, the upper intertidal limits of pink-reddish lithothamnioid algae, which is mainly a subtidal species, of the bull-kelp $D$. antarctica and of the kelp M. pyrifera occur around the Mean Low Water Neap (MLWN, Lewis 1964; also see Santelices \& Ojeda 1984, Meneses 1993). Therefore, we measured the rise in the upper limit of lithothamnioids and of dead holdfasts of M. pyrifera and D. antarctica as pre-earthquake markers. On Santa María island and at mainland sites the lower limit of the intertidal belt-forming mussel
Perumytilus purpuratus was also located around the MLWN (see Fig. 2a for post-earthquake measures). Therefore, as an indication of tidal height for uplift measures of the 4 belt-forming biomarkers, we refer to MLWN that in 2009 was $0.23 \mathrm{~m}$, relative to zero datum. Uplift measurements of the biomarkers on Santa María and at the mainland sites were done in situ using a $1 \mathrm{~m}$ scale placed vertically at the water level at low and high tide and by projecting this level horizontally back to the rock face, where the pre-earthquake beltforming biomarkers were located. When elevations were $>1 \mathrm{~m}$, a 5-m tape measure (1 cm accuracy) was used to measure the vertical change. Date and hour of low and high tide measurements were noted and tide levels were corrected using interpolations as reported by the Hydrographic and Oceanographic Service of the Chilean Navy.

\section{RESULTS}

Regardless of the intertidal biomarker used, the mean uplift on Santa María Island ranged between 2.1 and $3.1 \mathrm{~m}$ for the northern end, 2.1 and $2.4 \mathrm{~m}$ for the center and $2.4 \mathrm{~m}$ for the southern end of the island. On the mainland, elevations reached $1.9 \mathrm{~m}$ at Punta Lavapié. Punta Lavapié is close to Caleta Tubul, a site where FitzRoy and Darwin made observations, but we could not use Tubul because the site was covered by a landslide. At Caleta Tumbes and Mocha Island, we detected only minor uplifts of $\sim 0.2$ to $0.3 \mathrm{~m}$, where only the peaks of some subtidal rocks were raised above MLWN (Table 1). Since the maximum tidal range in the study area is $\sim 2 \mathrm{~m}$ (Tablas de marea de la costa de Chile 2010), most of the uplifted areas were moved above the upper tide limit. Further evidence of the uplift was the presence of wide areas with infralittoral specimens of the kelps Macrocystis pyrifera and Durvillaea antarctica and the mid-low intertidal belt of the mussel Perumytilus purpuratus that was dry and completely exposed to air during low and high tides (Fig. 2 a,b). At 5 of the 9 sites visited, dramatic uplifts occurred, and we recorded $100 \%$ mortality for all beltforming intertidal and shallow subtidal organisms (Table 2). The exceptions to these catastrophic biotic events were Caleta Tumbes and Mocha Island, where we detected relatively minor uplifts and where intertidal and shallow subtidal communities appeared normal without extensive evidence of invertebrate or algae mortality; however, a few boulders were carried higher into the intertidal by the tsunami.

In addition, at the uplifted sites we recorded catastrophic mortalities of several intertidal rocky shore and shallow subtidal edible/commercial species, regularly gathered during low tides by hundreds of artisan 

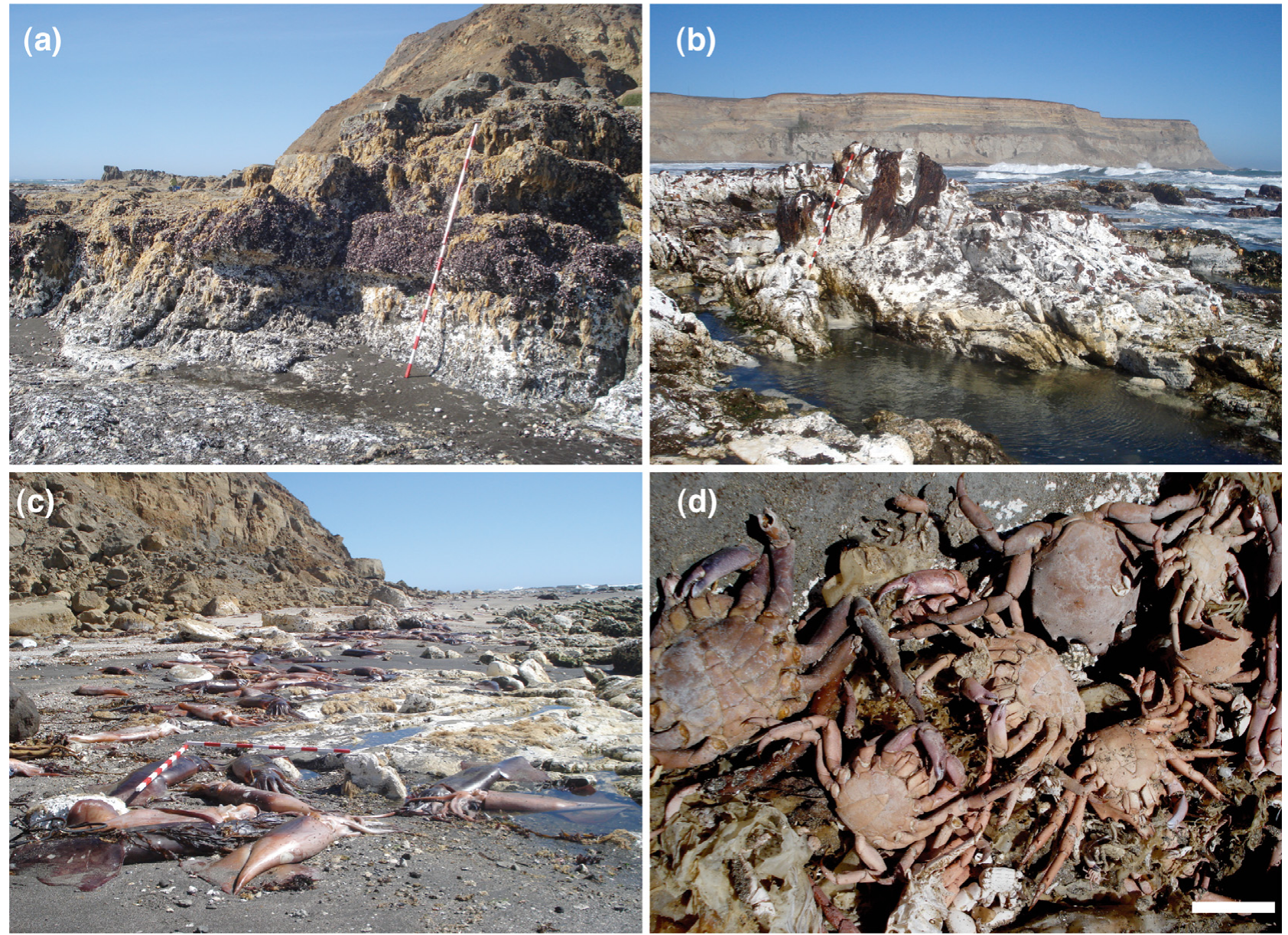

Fig. 2. Photographic record of coseismic uplift and the massive stranding of marine invertebrates at the northern end of Santa María Island after the February 2010 earthquake-tsunami. (a) Intertidal uplifted rocks showing belt of the mussel Perumytilus purpuratus; (b) low intertidal-infralittoral rocks with specimens of the brown kelp Macrocystis pyrifera and bull-kelp Durvillaea antarctica; (c) stranded giant jumbo squid Dosidicus gigas; (d) specimens of crab Taliepus spp. Photographs taken at (a,b) Las Gaviotas and (c,d) La Ballenera, northwest and northeast of Santa María Island, respectively (all photographs taken on 13 April 2010). $(\mathrm{a}, \mathrm{b})$ Whitish coloration represents dead lithothamnioids after being exposed to air due to uplift. Scale bar: (a-c) $2 \mathrm{~m}$ long with white and red sections of $0.1 \mathrm{~m}$ each and (d) $3 \mathrm{~cm}$

Table 1. Mean \pm SD rocky intertidal uplift $(\mathrm{m})$ associated with the Chilean earthquake of 27 February 2010. Upper or lower limits of dead specimen of kelp (holdfast), lithothamnioid coralline algae and mussels were used as pre-earthquake biomarkers for intertidal uplift at 8 sites where measurements were done. Height measurements $\left(n=20\right.$ site $\left.^{-1}\right)$ of the limits of belt-forming species were taken in situ over haphazardly selected areas and then referred to Mean Low Water Neap (MLWN) tides. (-): absence of data

\begin{tabular}{|c|c|c|c|c|c|c|c|c|}
\hline & \multicolumn{4}{|c|}{ - Santa María Island } & \multicolumn{2}{|c|}{ Mocha Island } & \multicolumn{2}{|c|}{ Mainland } \\
\hline & $\begin{array}{c}\mathrm{La} \\
\text { Ballenera }\end{array}$ & $\begin{array}{l}\text { Punta } \\
\text { Gaviota }\end{array}$ & $\begin{array}{l}\text { Las } \\
\text { Dolores }\end{array}$ & $\begin{array}{l}\text { Puerto la } \\
\text { Chota }\end{array}$ & $\begin{array}{l}\text { Muelle } \\
\text { Viejo }\end{array}$ & $\begin{array}{l}\text { Punta } \\
\text { Chales }\end{array}$ & $\begin{array}{l}\text { Punta } \\
\text { Lavapié }\end{array}$ & $\begin{array}{l}\text { Caleta } \\
\text { Tumbes }\end{array}$ \\
\hline $\begin{array}{l}\text { Upper limit of dead } \\
\text { lithothamnioids }\end{array}$ & $2.9 \pm 0.2$ & $3.0 \pm 0.2$ & - & $2.2 \pm 0.1$ & $0.2 \pm 0.1$ & $0.3 \pm 0.2$ & $1.6 \pm 0.1$ & $0.2 \pm 0.1^{a}$ \\
\hline $\begin{array}{l}\text { Upper limit of dead } \\
\text { Durvillaea antarctica }\end{array}$ & - & $3.0 \pm 0.2$ & $2.1 \pm 0.1$ & - & - & - & - & - \\
\hline $\begin{array}{l}\text { Upper limit of dead } \\
\text { Macrocystis pyrifera }\end{array}$ & $2.7 \pm 0.2$ & $2.9 \pm 0.2$ & $1.9 \pm 0.1$ & - & - & - & - & - \\
\hline $\begin{array}{l}\text { Lower limit of dead } \\
\text { Perumytilus purpuratus }\end{array}$ & $2.8 \pm 0.1$ & $3.1 \pm 0.2$ & $2.2 \pm 0.1$ & - & - & - & $1.9 \pm 0.2$ & $0.4 \pm 0.3$ \\
\hline
\end{tabular}


Table 2. Mortality, density and sizeparameters of intertidal belt-forming (A) macroalge and (B) encrusting algae and the mussel Perumytilus purpuratus on Santa María Island (Las Gaviotas) and adjacent mainland rocky intertidal platforms following the Chilean earthquake of 27 February 2010. Macrocystis pyrifera: low intertidal and shallow subtidal; Lessonia nigrescens: low intertidal; Durvillaea antarctica: low intertidal and shallow subtidal; Lithothamnioids and Corallina spp.: mainly subtidal; $P$. purpuratus: mid-intertidal .SMI: Santa María Island, MPL: Mainland Punta Lavapié, MCT: Mainland Caleta Tumbes. Quadrats: number of hapharzardly placed quadrats of $1 \mathrm{~m}^{2}$ used to assess the density and cover of belt-forming species. Where applicable, values are mean \pm SD. (-): absence of data. 100 specimens were used in each case to measure holdfast diameter and mussel size

\begin{tabular}{|lccccc|}
\hline A & Site & Quadrats (n) & Mortality (\%) & Density (ind. m ${ }^{-2}$ ) & Max. holdfast diameter (cm) \\
\hline Macrocystis pyrifera & SMI & 24 & 100 & $12.3 \pm 7.9$ & $14.31 \pm 3.2$ \\
Lessonia nigrescens & SMI & 25 & 100 & $5.0 \pm 1.9$ & $14.87 \pm 6.9$ \\
Durvillaea antarctica & SMI & 25 & 100 & $10.8 \pm 4.9$ & $25.40 \pm 5.9$ \\
B & Site & Quadrats (n) & Mortality (\%) & Rock cover (\%) & Mean length (cm) \\
\hline Lithothamnioids and Corallina spp. & SMI & 25 & 100 & $90.2 \pm 10.8$ & - \\
& MPL & 20 & 100 & $90.5 \pm 9.9$ & - \\
Perumytilus purpuratus & MCT & - & 100 & - & $2.5 \pm 0.6$ \\
& SMI & 25 & 100 & $84.8 \pm 17.4$ & $2.3 \pm 0.3$ \\
& MPL & 20 & 100 & $86.1 \pm 11.9$ & $2.3 \pm 0.4$ \\
\hline
\end{tabular}

fishers. These species included Concholepas concholepas (muricid gastropod, locally known as loco), Fissurella spp (keyhole limpets, locally known as chapas or lapas), Pyura chilensis (tunicates, locally knows as piures), the Rhodymeniales Sarcothalia sp. (known as luga) and the Ceramiales Chondracanthus sp. (known as chicoria de mar). Furthermore, thousand of specimens of the giant jumbo squid Dosidicus gigas, crabs, sea urchins, chitons and snails, among other invertebrates, were stranded along the western and eastern coast of Santa María Island by the tsunami (Fig. 2c,d). According to locals, strandings on the northern tip and western coast of the island do not occur with any frequency on the island.

\section{DISCUSSION}

Ranges of uplifts based on intertidal vertical elevation of bleached lithothamnioid algae recently reported (Farías et al. 2010) for localities included in our study agree well with our measurements. Further, this study was the first quantification of coseismic uplifted massive mortalities of intertidal and shallow subtidal invertebrate and bioengineer species, such as the mussel Perumytilus purpuratus and the algae Macrocystis pyrifera and Lessonia nigrescens. These species offer shelter for hundreds of invertebrates within their beds or holdfasts (Cancino \& Santelices 1984, Prado \& Castilla 2006).

On the southeastern Pacific coast, coseismic deformations (Lomnitz 1970, Comte et al. 1986, Beck et al. 1998, Melnick et al. 2006, Ruegg et al. 2009, Madariaga et al. 2010, Farías et al. 2010) affect shallow infralittoral and intertidal communities. This causes large, sudden and rapid mortalities, the disruption of zonation patterns, the alteration of local biogeography and species composition, the enhancement of local and widespread patchiness and produces temporal changes in marine coastal ecosystems (for Chile: Castilla 1988, Castilla \& Oliva 1990, Ortlieb et al. 1996, present study). Also, in the southeastern Pacific, other sudden/cyclical drastic events, such as elevation of the oxygen minimum zone and ENSO, cause rapid mortality of the adult and early stages of pelagic species (Barber \& Chávez 1983, Bakun \& Broad 2003, Chávez et al. 2003), shallow subtidal shellfish species (Castilla \& Camus 1992) and intertidal rocky and sandy-beach communities (Tomicic 1985, Soto 1985, Arntz et al. 1987, 1988).

The ecological role of natural sudden and/or predictable disruption and catastrophes on natural marine populations and communities has been repeatedly addressed. For instance, Harris et al. (1984) experimentally demonstrated that for kelp forests, after a major natural disturbance, refuge facilitation (rather than inhibition or neutral effects) substantially contributed to the regeneration processes. Dayton \& Tegner (1984) reported that combined major disturbances regimes (strong winter storms and summer ENSO effects) may have long-lasting structural effects on Macrocsytis pyrifera communities. Paine (1979) experimentally demonstrated that local population persistence of the sea palm Postelsia palmaeformis required predictable annual disturbance regimes of moderate intensity, while infrequent, large-scale catastrophes may contribute little to sea palm population persistence. In the same vein, Castilla (1988) monitored substantial changes in the intertidal-shallow subtidal vertical distribution of the competitively dominant kelp Lessonia nigescens due to sudden rocky shore uplifts 
caused by an earthquake in 1985, along more than $150 \mathrm{~km}$ of the coast of central Chile. Ecologically negative consequences on mid-intertidal zonation in the area lasted for several years, encompassing several generations of the species involved (barnacles, mussels and kelps) and impinging on the resilience of the intertidal ecosystems (Castilla \& Oliva 1990).

Sudden or predicted drastic impacts effecting marine populations and communities have been regarded as natural erratic or cyclical unmitigated disasters (Castilla 1988). Large-catastrophic events translating into dramatic and rapid coastal biological disasters, such as that described here, may affect, for example, selection in impacted areas by disrupting gene flow from unaffected areas. Moreover, the recovery and resilience of marine populations or communities under scenarios with drastic and rapid catastrophes should be more challenging for species with direct development than for species with dispersive larval stages, because successful production of local offspring relies mainly on the survival of local parents. This highlights the value of the southeastern Pacific for studying the evolution of life history traits. Furthermore, understanding how marine populations, communities and ecosystems recover (van Nes \& Scheffer 2007) and deal with highly disrupted environmental conditions (Castilla \& Camus 1992) may have significance for management and conservation practices, as for example in connection with alterations of parental stocks and recruitment rates.

Acknowledgements. This study was supported by Arauco, Chile. We thank R. N. Hughes for early comments on this manuscript. We also thank S. Gelcich, M. Lee and M. E. Jara for help in the field and to 4 anonymous reviewers for their helpful comments. During this research, J.C.C. was part of FONDAP-CASEB grant $\mathrm{N}^{\circ}$ 1501-0001 and P.H.M. was under the tenure of FONDECYT grant $\mathrm{N}^{\circ} 1080023$.

\section{LITERATURE CITED}

Arntz W, Brey T, Tarazona J, Robles A (1987) Changes in the structure of a shallow sandy-beach community in Peru during an El Niño event. In: Payne A, Gulland J, Brink K (eds) The Benguela and comparable ecosystems. S Afr J Mar Sci 5:645-658

Arntz W, Valdivia E, Zeballos J (1988) The impact of El Niño 1982-84 on the commercially-exploited invertebrates (mariscos) of the Peruvian shore. Meeresforsch 32:3-22

Awata Y, Toda S, Kaneda H, Azuma T, Horikawa H, Shishikura M, Echingo T (2008) Coastal deformation associated with the 2007 Noto Hanto earthquake, central Japan, estimated from uplifted and subsided intertidal organisms. Earth Planets Space 60:1059-1062

Bakun A, Broad K (2003) Environmental 'loopholes' and fish population dynamics: comparative pattern recognition with focus on El Niño effects in the Pacific. Fish Oceanogr 12:458-473
Barber RT, Chávez FP (1983) Biological consequences of El Niño. Science 222:1203-1210

Beck S, Barrientos S, Kausel E, Reyes M (1998) Source characteristics of historic earthquakes along the central Chile subduction zone. J S Am Earth Sci 11:115-129

Bodin P, Klinger T (1986) Coastal uplift and mortality of intertidal organisms caused by the September 1985 Mexico earthquake. Science 233:1071-1073

Cancino JM, Santelices B (1984) Importancia ecológica de los discos adhesivos de Lessonia nigrescens Bory (Phaeophyta) en Chile central. Rev Chil Hist Nat 52:23-33

Carver GA, Jayko AS, Valentine DW, Li WH (1994) Coastal uplift associated with the 1992 Cape Mendocino earthquake, northern California. Geol 22:195-198

Castilla JC (1988) Earthquake-caused coastal uplift and its effect on rocky intertidal kelp communities. Science 242: $440-443$

Castilla JC, Camus PA (1992) The Humboldt-El Niño scenario: coastal benthic resources and anthropogenic influences, with particular reference to the 1982/1983 ENSO. S Afr J Mar Sci 12:703-712

Castilla JC, Oliva D (1990) Ecological consequences of coseismic uplift on the intertidal kelp belts of Lessonia nigrescens in central Chile. Estuar Coast Shelf Sci 31: 45-56

Chávez FP, Ryan J, Lluch-Cota SE, Niquen M (2003) From anchovies to sardines and back: multidecadal change in the Pacific Ocean. Science 299:217-221

> Comte D, Eisenberg A, Lorca E, Pardo M and others (1986) Chile earthquake of 3 March 1985. A repeat of previous great earthquakes in the region? Science 233:449-453

Darwin C (1839) Voyages of the Adventure and Beagle, Vol III. Journals and remarks 1832-1836. Henry Colburn, London

Darwin C (1846) Geological observations on South America. Smith, Elder, London

> Dayton PK, Tegner MJ (1984) Catastrophic storms, El Niño, and patch stability in a southern California kelp community. Science 224:283-285

Farías M, Vargas G, Tassara A, Carretier S, Baize S, Melnick D, Bataille K (2010) Land-level changes produced by the $M_{\mathrm{w}} 8.82010$ Chilean earthquake. Science 329:916

FitzRoy R (1839) Voyages of the Adventure and Beagle, Vol II. J L Cox \& Sons, London

- Harris LG, Ebeling AW, Laur DR, Rawley RJ (1984) Community recovery following storm damage: a case of facilitation in primary succession. Science 224:1336-1338

Lewis JR (1964) The ecology of rocky shores. English Universities Press, London

> Lomnitz C (1970) Major earthquakes and tsunamis in Chile during the period 1535 to 1955. Geol Rundsch 59:938-960

> Madariaga R, Marianne M, Vigny C, Campos J (2010) Central Chile finally breaks. Science 328:181-182

Marín A, Gelcich S, Araya G, Olea G, Espíndola M, Castilla JC (2010) The 2010 tsunami in Chile: devastation and survival of coastal small-scale fishing communities. Marine Policy 34:1381-1384

Melnick D, Bookhagen B, Echtler HP, Strecker MR (2006) Segmentation of megathrust rupture zones from forearc deformation patterns over hundreds to millions of years, Arauco Peninsula, Chile. Geol Soc Am Bull 118:1463-1480

Meneses I (1993) Vertical distribution of coralline algae in the rocky intertidal of northern Chile. Hydrobiologia 260/261: 121-129

National Academy of Sciences (1972) The Great Alaska earthquake of 1964. NAS Printing and Publishing office, Washington, DC 
Ortlieb L, Barrientos S, Guzmán N (1996) Coseismic coastal uplift and coralline algae record in Northern Chile: the 1995 Antofagasta earthquake case. Quat Sci Rev 15: 949-960

Paine RT (1979) Disaster, catastrophe, and local persistence of the sea palm Postelsia palmaeformis. Science 205:685-686

Prado L, Castilla JC (2006) The bioengineer Perumytilus purpuratus (Mollusca: Bivalvia) in central Chile: biodiversity habitat structural complexity and environmental heterogeneity. J Mar Biol Assoc UK 86:417-421

Ramírez-Herrera MT, Zamorano JJ (2002) Coastal uplift and mortality of coralline algae caused by a $6.3 \mathrm{Mw}$ earthquake, Oaxaca, Mexico. J Coast Res 18:75-81

Ruegg JC, Rudloff A, Vigny C, Madariaga R and others (2009) Interseismic strain accumulation measured by GPS in the seismic gap between Constitución and Concepción in

Editorial responsibility: Hans Heinrich Janssen,

Oldendorf/Luhe, Germany
Chile. Phys Earth Planet Inter 175:78-85

Santelices B, Ojeda FP (1984) Recruitment, growth and survival of Lessonia nigrescens (Phaeophyta) at various tidal levels in exposed habitats of central Chile. Mar Ecol Prog Ser 19:73-82

Soto R (1985) Efectos del fenómeno El Niño 1982-83 en ecosistemas de la I Región. Invest Pesq (Chile) 32:199-206

Tablas de marea de la costa de Chile (2010) Servicio hidrográfico y oceanográfico de la Armada de Chile. Pub SHOA 3009

Tomicic J (1985) Efectos del fenómeno El Niño 1982-83 en las comunidades litorales de la península de Mejillones. Inv Pesq (Chile) 32:209-213

van Nes EH, Scheffer M (2007) Slow recovery from perturbations as a generic indicator of a nearby catastrophic shift. Am Nat 169:738-747

Submitted: May 28, 2010; Accepted: September 15, 2010 Proofs received from author(s): November 8, 2010 